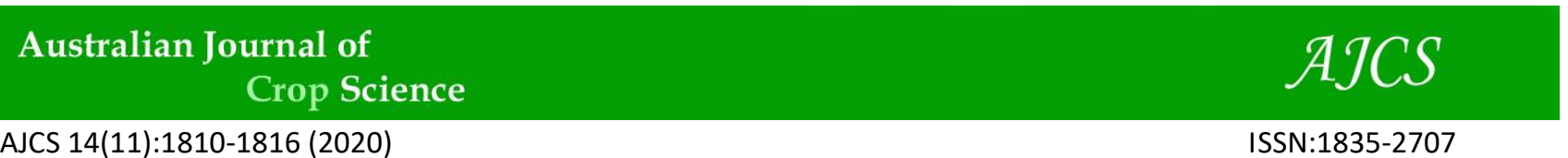

AJCS 14(11):1810-1816 (2020)

ISSN:1835-2707

doi: 10.21475/ajcs.20.14.11.p2187

\title{
Desorption isotherms and thermodynamic properties of Solanum gilo
}

\author{
Samuel Gonçalves Ferreira dos Santos ${ }^{1 *}$, Jefferson Kran Sarti ${ }^{2}$, Cassio da Silva Kran ${ }^{2}$, Hellismar Wakson da \\ Silva $^{3}$, Renato Souza Rodovalho ${ }^{2}$, Luís Sérgio Rodrigues Vale ${ }^{2}$, Daniel Pereira da Silva ${ }^{2}$, João César Reis \\ Alves $^{2}$, Daniel Emanuel Cabral de Oliveira ${ }^{4}$, Ivano Alessandro Devilla ${ }^{5}$
}

\author{
'Universidade Federal de Viçosa, Viçosa, Minas Gerais, Brazil \\ ${ }^{2}$ Instituto Federal Goiano, Ceres, Goiás, Brazil \\ ${ }^{3}$ Universidade Federal de Lavras, Lavras, Minas Gerais, Brazil \\ ${ }^{4}$ Instituto Federal Goiano, Iporá, Goiás, Brazil \\ ${ }^{5}$ Universidade Estadual de Goiás, Anápolis, Goiás, Brazil
}

\section{*Corresponding author: samuel-2100@hotmail.com}

Abstract

Solanum gilo is a plant belonging to the family Solanaceae with a probable origin in Africa. It was introduced to Brazil by workers. The fruit is cultivated by small producers in Brazil and it is a source of food for the low-income population. Its seeds are harvested with high moisture contents, and the drying process is necessary. Sorption isotherms consist of the relation between water activity $\left(a_{w}\right)$ and moisture content of an agricultural product at a constant temperature. This information contributes to the drying process, thus favoring an increased longevity of agricultural products, such as seeds. This research aims to determine the desorption isotherms of Solanum gilo seeds and calculate their thermodynamic properties (enthalpy, entropy and Gibbs free energy). Sorption experiments were performed by the gravimetric static method using saline solutions. Several mathematical models were fitted to the experimental data, and the selection of the best model was performed by statistical criteria. Equilibrium moisture contents were obtained at 10,20 and $30^{\circ} \mathrm{C}$ and at water activities between 0.111 and 0.985 (decimal). The modified Oswin model best represents moisture desorption isotherms of Solanum gilo seeds under the studied conditions. The energy required for the process was $0.22-555.68 \mathrm{~kJ} \mathrm{~kg}^{-1}$. The latent heat of vaporization $(\mathrm{L})$, the enthalpy $\left(\mathrm{Q}_{\mathrm{st}}\right)$, the entropy $(\Delta \mathrm{S})$ and the Gibbs free energy $(\Delta \mathrm{G})$ increased with the reduction of the equilibrium moisture content of seeds. The theory of isokinetics is valid for the desorption process.

Keywords: equilibrium moisture; enthalpy; Gibbs free energy; latent heat, isokinetic.

Introduction

Solanum gilo Raddi is a tropical vegetable. Its planting area has been increasing progressively in recent years (Alves, et al., 2017). It belongs to the Solanaceae family and its fruits are light green or dark green when unripe, becoming redorange when ripe. The fruit is fleshy and the seeds have high moisture contents after harvesting and extraction, requiring a drying process that reduces the moisture content to adequate levels, contributing to the increase in storage time (Majd et al. al., 2014). By means of the sorption process, the water content of seeds may increase or decrease during storage, resulting in a greater or a lesser activity of insects and microorganisms, thus changing the germination capacity (Corrêa et al., 2016) since seed longevity highly depends on the availability of water inside it (Bakhtavar et al., 2019).

Thus, sorption isotherms consist of the relation between water activity and moisture content of an agricultural product at a constant temperature (Resende et al., 2006). Understanding them is an essential factor in designs and studies on drying, handling, storage, packaging and transport systems and on the modeling of seed longevity (BustosVanegas et al., 2018). In addition, sorption isotherms can determine the physical, chemical and microbial stability of any product, as well as its water activity bands, which reduce the possibility of development of fungi and other pathogens besides maintaining the quality of the stored product (Goneli et al., 2007). Knowing the isotherms makes it possible to determine the isothermal heat of desorption (differential enthalpy), differential entropy and Gibbs free energy (Silva et al., 2018, Bustos-Vanegas et al., 2018, Goneli et al., 2010). These thermodynamic parameters provide information to calculate heating energy and mass transfer in biological systems, thus allowing a better understanding of the properties of water molecules (Goneli et al., 2016b).Due to the lack of information about the hygroscopicity of Solanum gilo, the present research aims to determine the desorption isotherms of Solanum gilo seeds and calculate their thermodynamic properties (enthalpy, entropy and Gibbs free energy).

Results

\section{Mathematical modeling and statistical criteria}

Table 3 shows the determination coefficient $\left(R^{2}\right)$, the standard deviation of the estimate (SDE) and the mean relative error (MRE) values of different mathematic models 
fitted to the experimental data of desorption isotherms of Solanum gilo seeds at different temperatures and water activity conditions. All models had coefficients of determination higher than 0.90. However, according to Corrêa et al. (2015), the isolated use of this parameter is not sufficient to characterize an adequate fitting of nonlinear models. Therefore, it is necessary to consider other statistical criteria.

The adequacy of mathematical models to a physical process is inversely proportional to the MRE (Draper and Smith, 1998), whose values must be lower than 10\% (Mohapatra and Rao, 2005). The Modified Halsey and Modified Oswin models showed MRE values lower than $10 \%$, and the Modified Oswin model had the lowest value for this parameter (MRE $=9.3929 \%$ ). According to Siqueira et al. (2012), the lower the SDE values, the better the fitting of the model to experimental data. The Modified Halsey and Modified Oswin models showed the lowest values (1.5721 and 1.7342) for this criterion (Table 3).

In relation to the distribution of residues, which consists of the differences between the values observed experimentally and values estimated by the model, only the Modified Halsey, Modified Oswin and Smith models presented a random distribution. Therefore, because they present the best statistical results (Table 3), the Modified Halsey and Modified Oswin models are suitable to represent the moisture desorption isotherms of Solanum gilo seeds. However, because it is a widely used model, the Modified Oswin model was selected.

\section{Desorption isotherms of Solanum gilo seeds}

The desorption isotherms of the Solanum gilo seeds estimated by the Modified Oswin model showed a sigmoidal shape characteristic of type II curves (Brunauer et al., 1938) (Figure 1), considered the standard for most agricultural products, such as sugar-beet seeds (Corrêa et al., 2016), cucumber (Corrêa et al., 2015), tomato (Sogi et al., 2003), and pepper (Capsicum sp.) (Ferreira et al., 2011; Rodovalho et al., 2015; Silva et al., 2015b; Silva and Rodovalho, 2016; Silva et al., 2018).

\section{Latent heat of vaporization}

The $L^{-1}$ ratio presented values higher than one for the entire range of equilibrium moisture content studied (Figure 2a), showing that the energy released by the seeds during the desorption process is always greater than the latent heat of vaporization from free water $\left(L^{\prime}=2,454.400 \mathrm{~kJ} \mathrm{~kg}^{-1}\right)$. The Equation 10 was used to calculate the values of each latent heat of vaporization of water according to temperature (Figure 2b). As moisture content increases, there is a decrease in the energy required for the evaporation of seed water (Sousa et al., 2016). At the temperatures of 10, 20 and $30^{\circ} \mathrm{C}$ and equilibrium moisture contents of $5.15-55.47 \%$ dry basis $(\mathrm{db})$, the latent heat of vaporization ranged from $6,366.05$ to $2,430.50 \mathrm{~kJ} \mathrm{~kg}^{-1}$ for Solanum gilo seeds.

\section{Enthalpy and Entropy}

The $\mathrm{Q}_{\text {hst }}$ (Figure 3a) and the $\Delta S$ (Figure $3 b$ ) increased with the reduction of the equilibrium moisture content of Solanum gilo seeds. $Q_{\mathrm{hst}}$ ranged from $5,782.897$ to $2,468.93 \mathrm{~kJ} \mathrm{~kg}^{-1}$ within the moisture content range of 5.15 to $55.47 \%(\mathrm{db})$, while $\Delta \mathrm{S}$ ranged from 9,793 to $0.047 \mathrm{~kJ} \mathrm{~kg}^{-1}$.

\section{Isokinetic Theory}

The representation of the enthalpy and entropy relation in the desorption process for Solanum gilo seeds indicates the applicability of the isokinetic theory to the desorption process. To validate the existence of this phenomenon, Krug et al. (1976a; b) established that the isokinetic temperature $\left(T_{B}\right)$ should be different from the mean harmonic temperature $\left(T_{\mathrm{hm}}\right)$. Thus, the isokinetic temperature obtained by Equation 16 was $327.7084 \pm 21.1854 \mathrm{~K}$, higher than the average harmonic temperature (292.9225 K), thus confirming the phenomenon provided for by the isokinetic theory for the desorption process of Solanum gilo seeds.

\section{Gibbs free energy}

The $\Delta G$ increased with the decrease in moisture content, whose values were positive for all temperatures studied with a tendency to stabilization. This property decreases with an increasing temperature. This can be explained by the higher degree of movement of molecules accelerating the mass exchange, thus accelerating the process at higher levels of equilibrium moisture content (Figure 4b) (Zeymer et al., 2018). Corrêa et al. (2015) verified this fact for cucumber seeds and Silva et al. (2018) for Malagueta pepper seeds.

\section{Regression equations}

The regression equations fitted to the $L L^{-1}$ ratio, isosteric heat, differential entropy and desorption Gibbs free energy. They presented a high degree of fitting to the experimental data $\left(R^{2}>0.97\right)$ (Table 4). Therefore, these equations can be used to estimate the thermodynamic parameters for the desorption process of Solanum gilo seeds for the range of equilibrium moisture content of 5.15 to $55.47 \%$ (db) and temperatures of 10,20 and $30^{\circ} \mathrm{C}$.

\section{Discussion}

The Modified Oswin model describes best the hygroscopicity of Solanum gilo seeds because it meets all statistical criteria. This model also show an adequate fitting to seeds of Malagueta pepper, Cumari Amarela pepper seeds, and Lactuca sativa seeds (Silva and Rodovalho, 2015; Ferreira et al., 2011; Zeymer et al., 2017). In relation to the desorption isotherms of Solanum gilo seeds, for a determined air temperature the increase in water activity makes it possible the increase in the equilibrium moisture content of seeds (Figure 1) due to the volume of water available in the air sorption environment. This is due to the increase in the air vapor pressure, causing a greater movement of water to the interior of the seeds (Goneli et al., 2010). Figure 1 shows that for a constant water activity, the values of hygroscopic equilibrium moisture content decrease with increasing temperatures, following the tendency of most agricultural products (Bustos-Vanegas et al., 2018; Zeymer et al., 2017). It can be observed that the $\mathrm{LL}^{-1}$ ratio is inversely proportional to the moisture content of Solanum gilo seeds. In another words, the higher the $\mathrm{LL}^{-1}$ ratio, the lower the moisture content in seeds (Figure $2 \mathrm{a}$ ). In relation to $\Delta \mathrm{hst}$, the reduction in moisture content leads to an increase in the 
Table 1. Water activity obtained by saline solutions at different temperatures.

\begin{tabular}{llll}
\hline \multirow{2}{*}{ Salt } & Temperature $\left({ }^{\circ} \mathrm{C}\right)$ & \\
\cline { 2 - 4 } & 10 & 20 & 30 \\
\hline $\mathrm{LiCl}$ & 0.111 & 0.117 & 0.111 \\
$\mathrm{MgCl}$ & - & 0.334 & 0.321 \\
$\mathrm{Mg}\left(\mathrm{NO}_{3}\right)_{2}$ & 0.570 & 0.546 & 0.525 \\
$\mathrm{NaCl}$ & - & 0.771 & 0.752 \\
$\mathrm{KCl}$ & 0.872 & 0.872 & 0.872 \\
$\mathrm{~K}_{2} \mathrm{SO}_{4}$ & 0.985 & 0.978 & 0.985 \\
\hline
\end{tabular}

Source: Labuza et al. (1985)

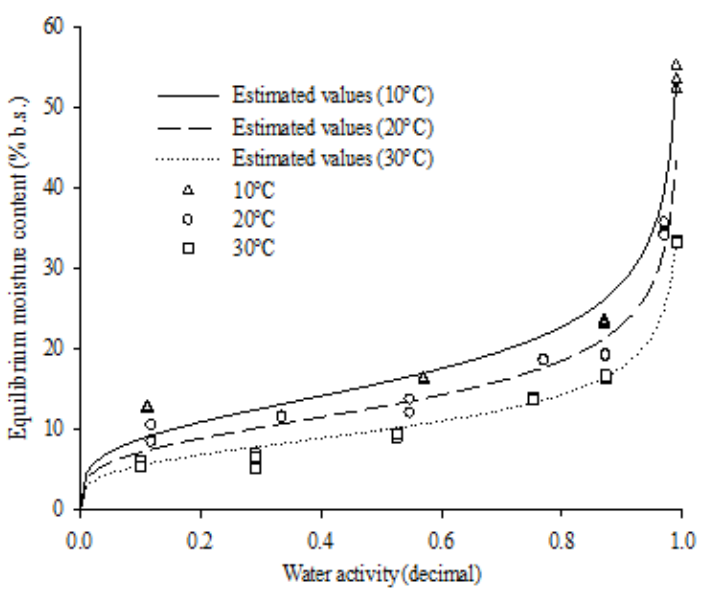

Fig 1. Experimental values of equilibrium moisture content and desorption isotherms estimated by the Modified Oswin model for Solanum gilo seeds

Table 2. Mathematical models used to represent desorption isotherms.

\begin{tabular}{llll}
\hline Expression & Model & $\mathrm{N}^{\circ}$ & Reference \\
\hline $\mathrm{Xe}=\mathrm{a}-\mathrm{b} \ln \left[-(\mathrm{T}+\mathrm{c}) \ln \left(\mathrm{a}_{\mathrm{w}}\right)\right]$ & Chung Pfost & (1) & $\begin{array}{l}\text { Chung and Pfost } \\
\text { (1967) }\end{array}$ \\
$\mathrm{Xe}=[\exp (\mathrm{a}-\mathrm{b} \mathrm{T}) /-\ln (\mathrm{aw})]^{1 / c}$ & Modified Halsey & (2) & Boquet et al. (1978) \\
$\mathrm{Xe}=\{\ln (1-\mathrm{aw}) /[-\mathrm{a}(\mathrm{T}+\mathrm{b})]\}^{1 / c}$ & Modified Henderson & Thompson et al. \\
$\mathrm{Xe}=(\mathrm{a}+\mathrm{b} \mathrm{T}) /\left[\mathrm{a}_{\mathrm{w}} /\left(1-\mathrm{a}_{\mathrm{w}}\right)\right]^{1 / c}$ & Modified Oswin & (1968) & Chen and Morey, \\
$\mathrm{Xe}=\mathrm{a}-(\mathrm{b} T)-\mathrm{c} \ln \left(1-\mathrm{a}_{\mathrm{w}}\right)$ & Smith & (1989) & Smith (1947) \\
\hline
\end{tabular}

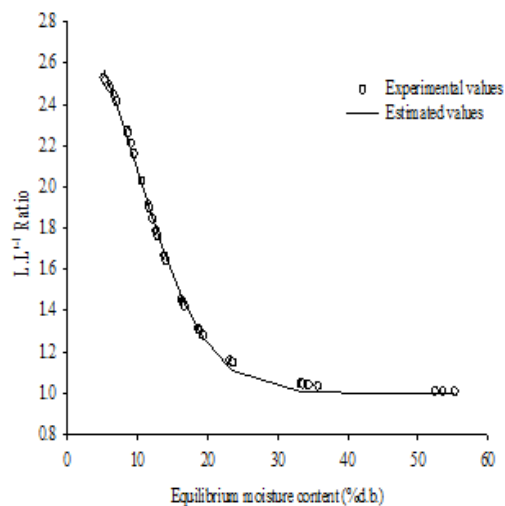

Fig 2. $L^{-1}$ ratio (a) and latent heat of desorption vaporization (b) as a function of the

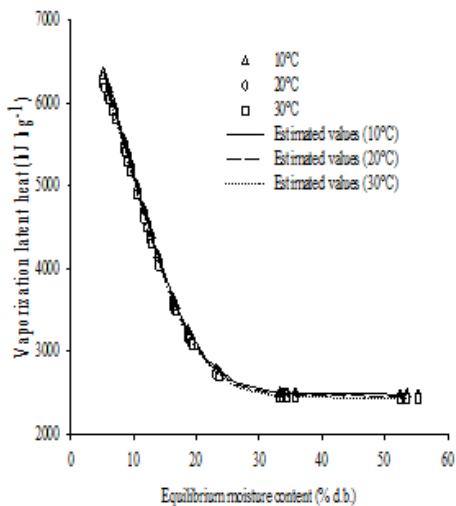

equilibrium moisture content of the Solanum gilo seeds 
Table 3. Determination coefficient $\left(R^{2}\right)$, mean relative error (MRE), standard deviation of the estimate (SDE), residue distribution (RD) and parameters for the models adjusted to water desorption isotherms of Solanum gilo seeds at 10,20 and $30^{\circ} \mathrm{C}$

\begin{tabular}{|c|c|c|c|c|c|c|c|}
\hline \multirow{2}{*}{ Model } & \multicolumn{3}{|c|}{ Parameter } & \multirow{2}{*}{$\mathrm{R}^{2}$} & \multirow{2}{*}{$\begin{array}{l}\text { SDE } \\
\text { (Decimal) }\end{array}$} & \multirow{2}{*}{$\begin{array}{l}\text { MRE } \\
\text { (\%) }\end{array}$} & \multirow{2}{*}{$\mathrm{RD}$} \\
\hline & $\mathrm{a}$ & $b$ & C & & & & \\
\hline 1 & $80.5228 *$ & 0.1599* & $-4.5095^{*}$ & 0.9201 & 3.5611 & 17.5801 & $B$ \\
\hline 2 & $9.8817^{*}$ & $0.0772^{*}$ & $3.4334^{*}$ & 0.9844 & 1.5721 & 9.5544 & A \\
\hline 3 & $0.0004 *$ & $9.0480 *$ & $1.5775^{*}$ & 0.9158 & 3.6547 & 19.8624 & B \\
\hline 4 & $18.7511^{*}$ & $-0.2931^{*}$ & $3.7745^{*}$ & 0.9810 & 1.7342 & 9.3929 & A \\
\hline 5 & $16.9412^{*}$ & $0.4808^{*}$ & $7.5417^{*}$ & 0.9509 & 2.7906 & 12.2444 & A \\
\hline
\end{tabular}

B- Residues, biased distribution, A- Residues, random distribution, *Significant at $5 \%$ probability by $t$ test

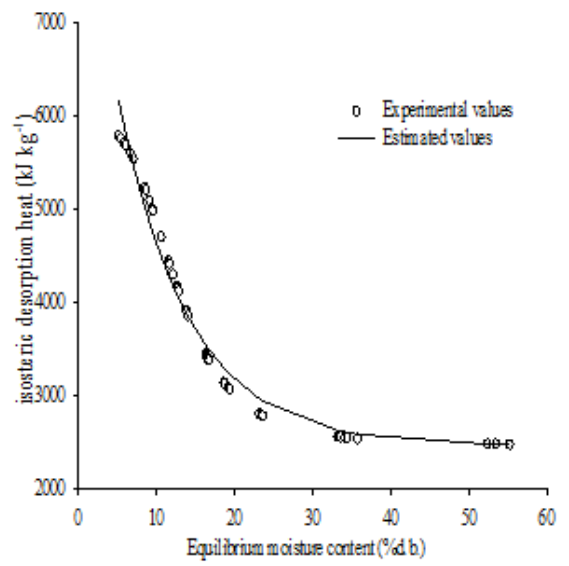

b

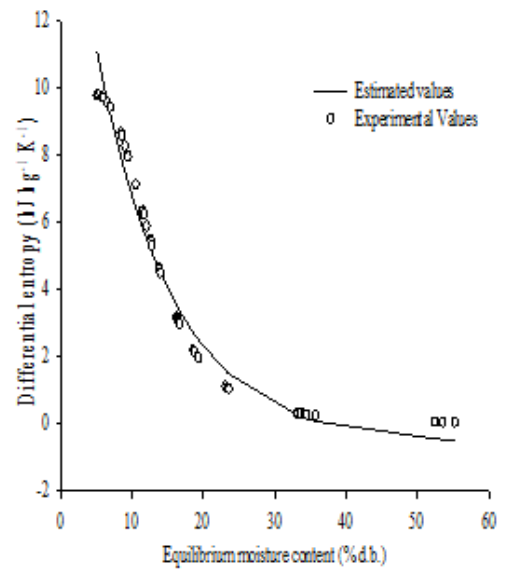

Fig 3. Isosteric heat of desorption (a) and differential entropy (b) as a function of the equilibrium moisture content of the seeds of Solanum gilo

Table 4. Regression equations and determination coefficients for the $L L^{-1}$ ratio, enthalpy $\left(\Delta_{\text {hst }}\right)$, entropy $(\Delta S)$ and Gibbs free energy $(\Delta \mathrm{G})$ of desorption in function of the equilibrium moisture content of Solanum gilo seeds.

\begin{tabular}{ll}
\hline Regression equation & $\mathrm{R}^{2}$ \\
\hline $\mathrm{L} \mathrm{L}^{\prime-1}=1+1.8014^{*} \exp \left(-0.0053^{*} \mathrm{Xe} \mathrm{e}^{1.9787^{*}}\right)$ & 0.9979 \\
$\left.\Delta \mathrm{H}_{\mathrm{st}}=6536.6932^{*} \exp \left(-0.2262^{*} \mathrm{Xe}\right)+2454.400\right)$ & 0.9808 \\
$\Delta \mathrm{S}=-0.5784^{*}+18.8728^{*} \exp \left(-0.0936^{*} \mathrm{Xe}\right)$ & 0.9762 \\
$\Delta \mathrm{G}=\left(-11095.6986^{*} \ln (\mathrm{T})+64249.8014^{*}\right) \exp \left(-0.1929^{*} \mathrm{Xe}\right)$ & 0.9875
\end{tabular}

*Significant by t-test $(\mathrm{p}<0.05)$.

a

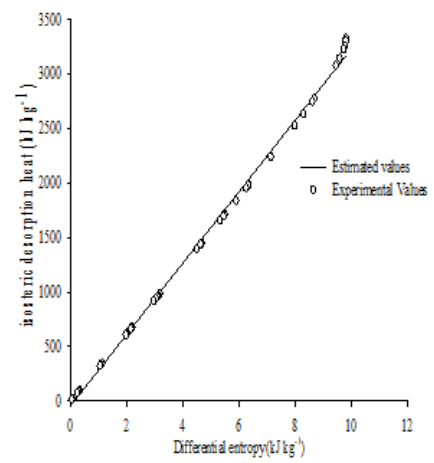

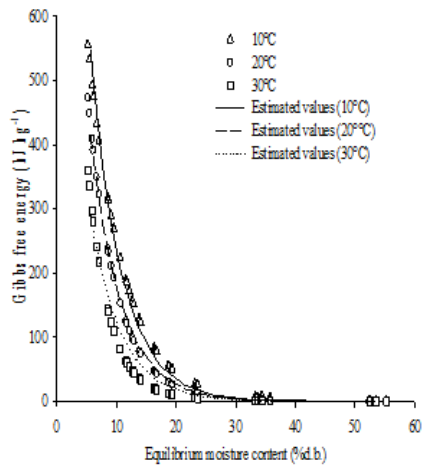

Fig 4. Linear enthalpy-entropy relationship for the desorption process (a) and experimental and estimated values of Gibbs free energy as a function of the temperature and equilibrium moisture content of Solanum gilo seeds (b) 
energy required for the removal of water from Solanum gilo seeds (Resende et al., 2006; Sousa et al., 2016).

There is a strong dependence of $\Delta S$ on the equilibrium moisture content of Solanum gilo seeds. The increase in the moisture content of seeds leads to a decrease in $\Delta \mathrm{S}$ (Figure $3 \mathrm{~b})$. This behavior is related to the mobility of water molecules present during the desorption process. With a high water activity, there are fewer sites available for bonds between molecules, implying a lower mobility demand of water molecules (Goneli et al., 2010). Similar results were observed for quinoa seeds (Bustos-Vanegas et al., 2018), okra seeds (Goneli et al., 2010), and Malagueta pepper seeds (Silva et al., 2018).

The isokinetic temperature needs all the sequence reactions occurring at the same time. It has been used to characterize the temperature at which the product is in equilibrium (Corrêa et al., 2015, Goneli et al., 2016b). According to Leffler (1955), if $T_{B}>T_{h m}$, the sorption process is controlled by enthalpy; otherwise $\left(T_{B}<T_{h m}\right)$, the process is controlled by entropy. Thus, the desorption process of Solanum gilo seeds is controlled by enthalpy, following the same behavior of several agricultural products (Silva et al., 2018, BustosVanegas et al., 2018; Goneli et al., 2016b).

A positive value for $\Delta G$ characterizes an endothermic reaction (Silva et al., 2016; Goneli et al., 2016b), that is, a reaction that needs energy for moisture sorption. Therefore, for the reduction of the equilibrium moisture content of Solanum gilo seeds, it is necessary to supply energy to the system, thus characterizing a non-spontaneous process (Figure 4b).

\section{Materials and methods}

\section{Obtaining and extracting Solanum gilo seeds}

The present research was developed at the Laboratory of Seed Analysis of the Federal Institute of Education, Science and Technology Goiano Campus Ceres, municipality of Ceres, GO, Brazil. Seeds of Solanum gilo, cultivar Tinguá Light Green, produced in the Campus, were used. The campus coordinates are $15^{\circ} 16^{\prime} 30^{\prime \prime} \mathrm{S}$ and $49^{\circ} 35^{\prime} 54^{\prime \prime} \mathrm{W}$ of the quadrant 22L. After harvest, the fruits were sent to the Laboratory of Seed Analysis, where the extraction of seeds was performed manually using disposable blades.

The seeds were pre-dried under natural laboratory conditions with a mean temperature of $24.98^{\circ} \mathrm{C}$ and $74.88 \%$ relative humidity for $48 \mathrm{~h}$ for the removal of excess moisture content up to $30 \%$ wet basis (wb) for the desorption experiments.

\section{Obtaining the desorption isotherms of Solanum gilo seeds}

The desorption isotherms of Solanum gilo seeds were obtained using the static gravimetric method at 10, 20 and $30^{\circ} \mathrm{C}$ and aw within the range 0.111 to 0.985 (decimal). The seeds were deposited in hermetic glass containers. $36 \mathrm{~g}$ of Solanum gilo seeds were used for each temperature under study. There were three replicates for each $a_{w}$. The temperature was controlled by a B.O.D chamber (biochemical oxygen demand). The $a_{w}$ was obtained using saturated salt solutions (Table 1 ).

The samples were weighed periodically until reaching the hygroscopic equilibrium, when the mass remained constant during three consecutive weighing sets. The moisture content of the seeds was determined by the oven method at $105 \pm 3^{\circ} \mathrm{C}$ for $24 \mathrm{~h}$ (BRASIL, 2009).

The mathematical models fitted the experimental desorption data frequently used to represent the hygroscopicity of agricultural products. The equations are presented in Table 2.

\section{Statistical analyses and obtaining thermodynamic properties}

The fitting of the mathematical models was performed by non-linear regression analysis using the Gauss Newton method at 0.05 probability of the $t$ test. The degree of fitting was verified by the magnitude of the coefficient of determination $\left(R^{2}\right)$, the mean relative error (MRE), the standard deviation of the estimate (SDE), and the residual distribution (Corrêa et al., 2016, Goneli et al., 2016a). MRE and SDE were calculated using the following expressions:

MRE $=\frac{100}{n} \sum_{i=1}^{n}\left(\frac{|Y-\widehat{Y}|}{Y}\right)$

$\mathrm{SDE}=\sqrt{\frac{\sum_{\mathrm{i}=1}^{\mathrm{n}}(\mathrm{Y}-\hat{\mathrm{Y}})^{2}}{\mathrm{DF}}}$

In which:

$\mathrm{Y}$ - experimental value; $\hat{\mathrm{Y}}$ - value estimated by the model; $\mathrm{n}$ number of experimental observations; DF - degrees of freedom of the model.

In the selection of mathematical models, it was recommended the model that obtained the highest $R^{2}$, the lowest SDE, a MRE below $10 \%$ and a random distribution of residues. Regarding residue distribution, it was considered random when the residual values were in a horizontal zone close to zero.

The $L L^{-1}$ ratio was calculated from the Clausius-Clapeyron Equation (8), whose data were fitted by the Rodrigues-Arias Equation (9), and then the latent heat of water vaporization seeds (10) for each temperature and water content studied (Corrêa et al., 1998).

$$
\begin{aligned}
& \operatorname{Ln}(P v)=\frac{L}{L^{\prime}} \operatorname{Ln}(P v s)+C \\
& \frac{L}{L^{\prime}}-1=a \exp \left(-b X^{m}\right) \\
& L=(2502.2-2.39 T)\left(1+a \exp \left(-b X e^{m}\right)\right.
\end{aligned}
$$

In which:

Pv - free water vapor pressure at a given equilibrium temperature, $\mathrm{kPa}$; Pvs - saturation vapor pressure of free water at a given equilibrium temperature, $\mathrm{kPa}$; $\mathrm{L}$ - latent heat of water vaporization of the product, $\mathrm{kJ} \mathrm{kg}^{-1} ; \mathrm{L}^{\prime}$ - latent heat of vaporization of the free water, equilibrium temperature, $\mathrm{kJ} \mathrm{kg}^{-1} ; \mathrm{C}$ - integration constant; and, $\mathrm{a}, \mathrm{b}, \mathrm{m}$ coefficients that depend on the product; $\mathrm{T}$ - temperature in Kelvin.

The isosteric heat of desorption or differential enthalpy (11), the differential entropy (12), the isokinetic theory (15 and $16)$, and the Gibbs free energy (14) were calculated by the methodology described by Corrêa et al. al. (2012), according to the following expressions:

$\ln \left(\mathrm{a}_{\mathrm{w}}\right)=\frac{\Delta \mathrm{h}_{\mathrm{st}}}{\mathrm{RT}}-\frac{\Delta \mathrm{S}}{\mathrm{R}}$ 
$\Delta \mathrm{S}=\frac{\Delta \mathrm{h}_{\mathrm{st}}-\Delta \mathrm{G}}{\mathrm{T}_{\mathrm{a}}}$

$\Delta \mathrm{h}_{\mathrm{st}}=\mathrm{T}_{\mathrm{B}}(\Delta \mathrm{S})+\Delta \mathrm{G}_{\mathrm{B}}$

$\Delta \mathrm{G}=\mathrm{R} \mathrm{T}_{\mathrm{a}} \ln \left(\mathrm{a}_{\mathrm{w}}\right)$

$\mathrm{T}_{\mathrm{hm}}=\frac{\mathrm{n}}{\sum\left(\frac{1}{\mathrm{~T}}\right)}$

$\mathrm{T}_{\mathrm{B}}=\hat{\mathrm{T}}_{\mathrm{B}} \pm \mathrm{t}_{\mathrm{m}-2, \alpha / 2 \sqrt{\operatorname{Var}\left(\mathrm{T}_{\mathrm{B}}\right)}}$

Where:

$\Delta \mathrm{h}_{\text {st }}$ - integral isosteric heat or differential desorption enthalpy, $\mathrm{kJ} \mathrm{kg}^{-1} ; \Delta \mathrm{S}$ - differential desorption entropy $\left(\mathrm{kJ} \mathrm{kg}^{-1}\right.$ $\left.\mathrm{K}^{-1}\right) ; \Delta \mathrm{G}$ - Gibbs free energy $\left(\mathrm{kJ} \mathrm{kg}^{-1}\right) ; \mathrm{T}_{\mathrm{B}}$ - isokinetic temperature $(\mathrm{K}) ; \mathrm{T}_{\mathrm{hm}}$ - mean harmonic temperature $(\mathrm{K}) ; \mathrm{n}$ number of temperatures used; $\mathrm{m}$ - number of entropy and entropy data pairs.

\section{Conclusions}

The Modified Oswin model best represents the desorption isotherms of moisture of Solanum gilo seeds at 10, 20 and $30^{\circ} \mathrm{C}$ and water activity within the range 0.111 to 0.985 (decimal). The latent heat of vaporization, isosteric heat, differential entropy and Gibbs free energy increase with the reduction of the equilibrium moisture content of seeds.

The enthalpy-entropy compensation phenomenon is valid for the moisture desorption process in Solanum gilo seeds, which is controlled by enthalpy.

\section{Acknowledgments}

This research was supported by the Federal Institute Goiano (Ceres campus), Foundation of Research Support of the State of Goiás (FAPEG), and Brazilian National Council for Scientific and Technological Development (CNPq). To the Federal Institute of Education, Science and Technology Goiano Campus Ceres for financial support.

\section{References}

Alves CZ, Godoi AR, Candido ACS, Oliveira NC (2012) Qualidade fisiológica de sementes de jiló pelo teste de envelhecimento acelerado. CIENC RURAL. 42:58-63.

Bakhtavar MA, Afzal I, Basra SMA (2019) Moisture adsorption isotherms and quality of seeds stored in conventional packaging materials and hermetic Super Bag. PLOS ONE. 14: 1-11.

Boquet R, Chirife J, Iglesias H (1978) Equations of fitting water sorption isotherms of foods. J FOOD TECHNOL. 2:329-327.

Brasil. Ministério da Agricultura, Pecuária e Abastecimento (2009). Regras para análises de sementes / Ministério da Agricultura Pecuária e Abastecimento. Secretaria Nacional de Defesa Agropecuária. Brasília: MAPA/ASC. 399p.

Brunauer S, Emmett PH, Teller E (1938) Adsorption of gases in multimolecular layer. JACS. 60:309-319.

Bustos-Vanegas, JD Corrêa PC, Zeymer JS (2018) Moisture sorption isotherms of Quinoa seeds: Thermodynamic Analysis. ENG AGR-JABOTICABAL. 38: 941-950.
Chen CC, Morey V (1989) Comparison of four EMC/ERH equations. T ASABE. 32:983-990.

Chung DS, Pfost HB (1967) Adsorption and desorption of water vapors by cereal grains and their products Part II. T ASABE. 10:549-551.

Corrêa PC, Christ D, Martins JH, Mantovani BHM (1998) Curvas de dessorção e calor latente de vaporização para as sementes de milho pipoca (Zea mays). REV BRAS ENG AGR AMB. 2:75-79.

Corrêa PC, Oliveira GHH de, Oliveira APLR de, Goneli ALD, Botelho FM (2016) Isotermas de dessorção de sementes de beterraba. REVENG. 24:15-21.

Corrêa PC, Oliveira GHHD, Santos EDS (2012) Thermodynamic properties of agricultural products processes. In: Arana, I. Physical properties of foods: Novel measurement techniques and applications. Boca Raton: CRC Press, 2012. p.131-141.

Corrêa PC, Reis MFT, Oliveira GHH de, Oliveira APLR de, Botelho FM (2015) Moisture desorption isotherms of cucumber seeds: modeling and thermodynamic properties. JSS. 37:218-225.

Draper NR, Smith H (1998) Applied regression analysis. 3 ed. New York: John W, Sons. (3): 1998. 736p.p.

Ferreira SCDS, Silva HWD, Rodovalho RS (2011) Isotermas de dessorção e calor latente de vaporização da semente de pimenta Cumari Amarela (Capsicum chinense L.). Revista Liberato. 13:1-16.

Goneli ALD, Corrêa PC, Oliveira GHHD, Oliveira APLRD, Orlando RC (2016) Moisture sorption isotherms of castor beans. Part 2: Termodynamic properties. REV BRAS ENG AGR AMB. 20:757-762.

Goneli ALD, Corrêa PC, Oliveira GHHD, Resende O (2016) Mauad, M. Moisture sorption isotherms of castor beans REV BRAS ENG AGR AMB. 20:751-756.

Goneli ALD, Corrêa PC, Oliveira GHHD, Botelho FM (2010) Water desorption and thermodynamic properties of okra seeds. T ASABE, St. Joseph. 53: 191-197.

Goneli ALD, Corrêa PC, Resende O, Nogueira BL, Botelho FM (2007) Modelagem matemática do equilíbrio higroscópico dos grãos de arroz em casca obtidos pelos métodos estático e dinâmico. Revista Brasileira de Armazenamento. 32:152-160.

Krug RR, Hunter WG, Grieger RA (1976) Enthalpy-entropy compensation: 1 - some fundamental statistical problems associated with the analysis of Van't Hoff and Arrhenius data. J PHYS CHEM-US. 80:2335-2341.

Krug RR, Hunter WG, Grieger RA (1976) Enthalpy-entropy compensation: 2 - separation of the chemical from the statistical effect. J PHYS CHEM-US. 80:2341-2351.

Labuza TP, Kaauane A, Chen JY (1985) Effect of temperature on the moisture sorpion isotherms and water activity shift of two dehydrated foods. J FOOD SCI. 50:385-391.

Maleki K, Karparvarfard SH, Farahnakv A, Ansari S, (2014) Thermodynamic properties of water sorption isotherms of grape seed. INT AGROPHYS. 28:63-71.

Mohapatra D, Rao PS (2005) A thin layer drying model of parboiled wheat. J FOOD ENG. 66:513-518.

Resende O, Corrêa PC, Goneli ALD, Ribeiro DM (2006) Isotermas e calor isostérico de sorção do feijão. CIENCIA TECNOL ALIME. 26:626-631.

Rodovalho RS, Silva IL, Silva HWD, Rossetto CAV (2015) Isotermas de sorção dos grãos de pimenta bode. Revista Agrotecnologia. 6:80-101.

Silva HWD , Costa LM, Resende O, Oliveira DECD, Soares RS, Vale LSR (2015) Higroscopicidade das sementes de 
pimenta (Capsicum chinense L.). REV BRAS ENG AGR AMB. 19:780-784.

Silva HWD, Rodovalho RS (2016) Adsorption isotherms and vaporization latent heat of malagueta pepper seeds. Científica. 44:5-13.

Silva HWD, Rodovalho RS, Silva IL (2018) Hysteresis and thermodynamic properties of water sorption in 'Malagueta' pepper seeds. REV BRAS ENG AGR AMB. 22:658-663.

Smith, SE (1947) The sorption of water vapor by high polymers. JACS. 69: 646, 1947.

Sogi DS, Shivhare US, Garg SK, Bawa AS (2003) Water sorption isotherm and drying characteristics of tomato seeds. BIOSYST ENG. 84:297-301.
Sousa KD, Resende O, Carvalho BDS (2016) Determination of desorption isotherms, latent heat and isosteric heat of pequi diaspore. REV BRAS ENG AGR AMB. 20:493-498.

Thompson TL, Peart RM, Foster GH (1968) Mathematical simulation of corn drying - a new model. T ASABE. 11:582586.

Zeymer, JS, Corrêa PC, Oliveira GHHD, Baptestini FM, Freitas RCP (2017) Desorption isotherms of Lactuca sativa seeds. REV BRAS ENG AGR AMB. 21:568-572

Zeymer, JS, Corrêa PC, Oliveira GHHD, Baptestini FM, Faria IL (2018) Thermodynamic properties of sorption of rice in the husk. ENG AGR-JABOTICABAL. 38: 369-375 